\title{
Article \\ User Intention of Anonymous Social Application "Soul" in China: Analysis based on an Extended Technology Acceptance Model
}

\author{
Zhiyuan $\mathrm{Yu} *$ (D) and Xiaoxiao Song \\ School of Journalism and Communication, Shandong University, Jinan 250100, China; \\ songxiaoxiao@mail.sdu.edu.cn \\ * Correspondence: yuzhiyuan@sdu.edu.cn
}

Citation: Yu, Z.; Song, X. User Intention of Anonymous Social Application "Soul" in China: Analysis based on an Extended Technology Acceptance Model. J. Theor. Appl. Electron. Commer. Res. 2021, 16, 2898-2921. https:// doi.org/10.3390/jtaer16070159

Academic Editor: Mirjana Pejić Bach

Received: 12 August 2021

Accepted: 21 October 2021

Published: 25 October 2021

Publisher's Note: MDPI stays neutral with regard to jurisdictional claims in published maps and institutional affiliations.

Copyright: (c) 2021 by the authors. Licensee MDPI, Basel, Switzerland. This article is an open access article distributed under the terms and conditions of the Creative Commons Attribution (CC BY) license (https:/ / creativecommons.org/licenses/by/ $4.0 /)$.

\begin{abstract}
Anonymity is an inherent attribute of the Internet. Depending on pseudonyms, cyber citizens can role play and present themselves by reconstructing a different identity. In order to satisfy the needs of anonymous self-expression, anonymous social applications have become popular worldwide. In this paper, we conduct a survey regarding user intention (UI) of "Soul", which is a popular anonymous social media application in China, especially for the youth. For this purpose, we design an adapted technology acceptance model (TAM) consisting of seven influencing factors, i.e., perceived usefulness (PU), perceived ease of use (PEOU), perceived anonymity (PA), perceived privacy riskiness (PPR), subjective norms (SN), emotional attachments (EA) and perceived interactivity (PI). Both the measurement and structural models are tested via partial least squares structural equation model. The results show that PU, PEOU, PPR and PI have a significant relationship with UI. Therein, both SN and EA can impact PU, and meanwhile, the direct paths between PI $\rightarrow$ PEOU, $\mathrm{PA} \rightarrow$ PPR also exist. Contrary to expectation, the effect of SN on UI is not directly significant. The proposed model is able to explain $64.1 \%$ of variance for UI among Soul users. The results suggest that the proposed constructs provide relatively good explanations for the continuous intention to use the Soul app.
\end{abstract}

Keywords: anonymous social media; Soul application; technology acceptance model; user intention

\section{Introduction}

Nowadays, depending on the explosive developments of Information and Communications Technology (ICT), the use of social media and its applications has become the trend around the world, which dramatically alters content distribution. Social media is a representative product in Web 2.0, which combines the functions of decentralized open network models and cognition social models [1]. The advantages of social media can be described as participation, openness, communication, dialogue, community and connectivity [2-5]. The number of global social media users has dramatically increased from 2.21 billion in 2015 to 4.20 billion in 2021. The average time spent on social media reach 145 minutes per day [6]. Users can create diverse social identities in different social spaces by uploading their profiles [7].

In June 2021, the number of Internet users in China reached 1.011 billion and the internet penetration rate was $71.6 \%$. Among them, the amount of mobile Internet users was 1.007 billion. Therein, the proportion of Internet users using mobile phones to access the Internet was 99.6\% [8]. In this huge market, the development of anonymous social applications fills the gap beyond the "acquaintance circle" of social networking represented by WeChat, and meets the diverse social needs of social media users. In an anonymous environment, people can use social applications or software to relax, find solace, make friends and so on, which may lead to different usage behavior than that in non-anonymous situations [9]. The latest data shows that the size of China's anonymous social market 
reached 622 million in 2019, with more than $70 \%$ of the user age structure being under the age of 35 [10].

\subsection{Anonymous Social Media}

Anonymous social media (ASM) can be recognized as a subcategory of social media, characterized by the property of anonymity, originating from the Advanced Research Project Agency Network (ARPA net). For example, users of Usenet and Bulletin Board System (BBS) can interact and share anonymous information on web and mobile platforms [11-13]. On the one hand, ASM allow a social activity in which Internet users participate in an anonymous way, i.e., users conceal their real identities. On the other hand, ASM refers to the social activities of strangers conducted by Internet users with their real identities concealed, and belongs to the category of stranger social media (SSM). Differing from traditional social media, ASM make it easier for users to hide or better protect both their off-line and online identities [14]. Anonymous participation can satisfy users' psychological demands, e.g., voyeurism [15], attachments [16], self disclosure [17] etc., which attracts a large amount of social media users. However, anonymous participation can also cause a crisis of confidence and the spread of misinformation, e.g., online fraud and phishing attacks [18].

As presented in Table A1 of Appendix A, we divide the anonymous social applications into three phases, i.e., Internet, Web 1.0 and Web 2.0 era. In the Web 1.0 era, "anonymous tribes" in BBS and online forums were the early products of ASM. For example, Match.com provides a platform for users to make friends anonymously. While 4 chan was launched in 2003 , allowing users to post anonymously in a pool of related topics and browse comments anonymously. In Web 2.0, the functionalities of ASM tend to be more diverse. In China, QQ Mail launched the "Drift Bottle" function in 2010 and WeChat launched the location-basedservice (LBS) "People Nearby" function in 2011. Globally, Whisper Text LLC launched the anonymous social application Whisper in 2012, with 250 million monthly active users (MAU) from 187 countries [19]. China's first anonymous social app "Mimi" reformed "Wumi" builds the connection among acquaintances and has achieved great success.

In the era of Web 3.0, with the help of a unified identity system, data validation and authorization, privacy protection, anti-censorship and decentralized operations, data will be interconnected in a decentralized way, and users will be able to interact with machines and data [20]. The personalized recommendation mechanism becomes a basic and necessary function of social applications and software. Peers with similar interests will be gathered in a particular virtual community and share generated content after matching. For example, applications like Psst!, which can provide a chance for users to meet like-minded people anonymously through matching mechanisms. Meanwhile, users can share news, opinions, secrets, etc., based on the individual's regular behavior (e.g., clicks, posts and reads), and the efficiency and reliability of recommendation will be continuously improved. There is no doubt that anonymous social media will be evolved and user-friendly in Web 3.0 and beyond. However, the specific developments are still rooted in the market situation and user needs.

\section{2. "Soul"-Cial Metaverse for Young Generations}

With the trend of young people jumping out of traditional social networking, some technology companies driven by the digital transformation [21,22] propose personalized products and applications for youth. Soul, founded in 2016, is a niche social networking product and gradually becomes the popular algorithmic-driven app in China. It has created a timely "playground" for young generations with a user-friendly interface, as shown in Figure 1a,b. 


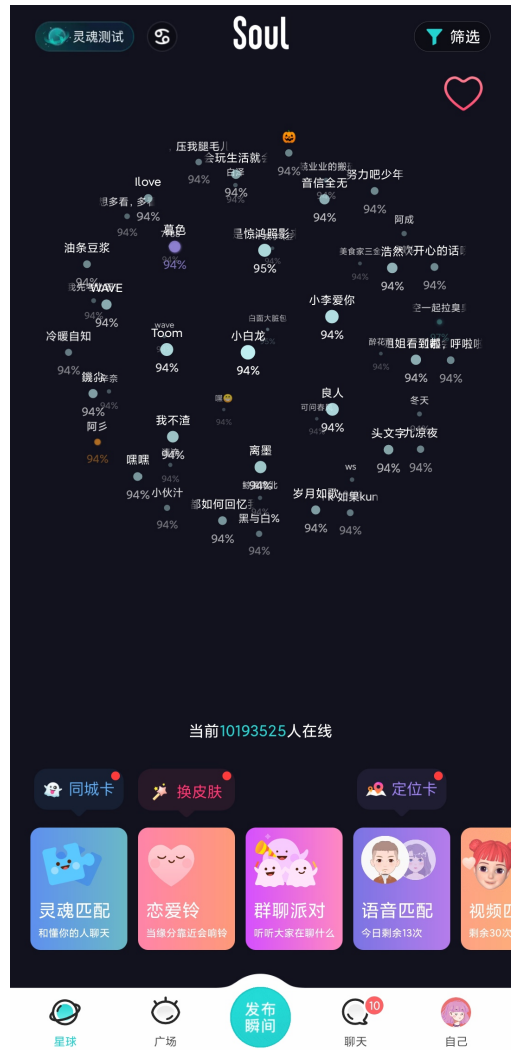

(a)
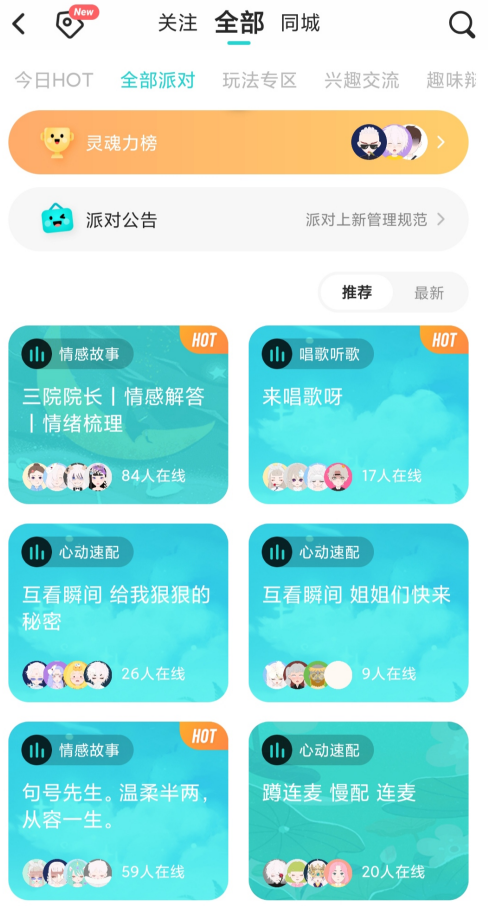

创建派对

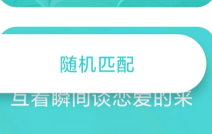

(b)

Figure 1. (a) Soul user interface with the functions of soul matching, love bell, group-chatting party, voice and video matching (from left to right at the bottom). (b) Group-chatting Party with different rooms.

Soul users (called "Soulers") can live in the home page named "moment" to express themselves and draw inspiration from each other's creativity. Compared to other anonymous social applications, Soul allows users to hide their real identities, locations, ages, appearance, etc., where the users' real profile does not need to be posted entirely. Soulers can post anonymously and set "invisible assistant" to achieve complete anonymity. The matching function is similar to Tinder uses chat boxes instead of swiping left and right. Nowadays, Soul has updated several new functions for young generations, e.g., radio chatting groups similar to Clubhouse, campus club similar to Yik Yak, LBS function "Love bell", game "Online Werewolf", Facekini video chatting, etc. Those function help to weaken the role of "Yanzhi" (appearance-oriented) in social interactions. Currently, Soul is a comprehensive anonymous social app that combines the functionalities of social networking, gaming and live streaming. The main functions and features are summarized as follows.

- Functions for young generations. Soul provides the four basic functions "Planet", "Square", "My own" and "Chat List", and also launched LBS matching "Love Bell" and "Campus Bar", anonymous voice room "Party room", electronic pets, "online werewolf killing room" and "Facekini" video matching.

- Voice-oriented socializing. Functions of Soul have weakened the role of "Yanzhi" (appearance-oriented) in social interactions, as users do not need to upload their real photos and can choose to chat with each other through text or voice when contacting strangers.

- Soul Coin Revenue Model. Soul primarily generates revenue from value-added services such as membership subscriptions. Users can buy memberships to become a 
"Chaojixingren"(VIP on Soul), or buy value-added services such as "check out who has seen me" and "location card" to match people nearby.

As a representative product of anonymous social app in China, Soul has accumulated more than 100 million registered users since its launch in 2016. In March 2021, the numbers of monthly active users and average daily active users (DAUs) were 33.2 million and 9.1 million, representing a growth of $109.0 \%$ and $94.4 \%$ over the same period in 2020 , respectively. The development conditions of Soul are shown in Figure 2. According to iiMedia Report, Soul app is quite popular among the youth (below 35 years old), which account for $84.04 \%$ of users [10]. From June 2020 to June 2021, Soul App has ranked in the top three social products (free) in China [23], which provides a typical example of an anonymous social app for user intention research.
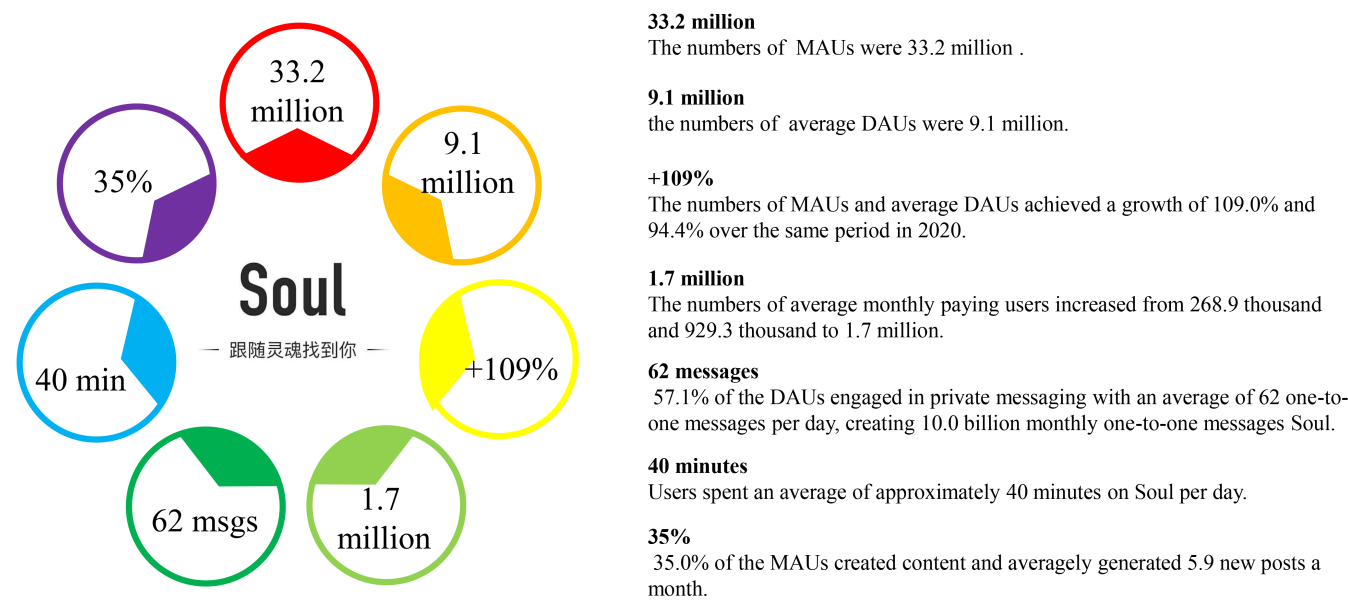

Figure 2. Overview of Soul from seven aspects (in March 2021) [24]. Data source: Form F-1. https: / / www.sec.gov/Archives/edgar/data/1832879/000119312521156430/d109555df1.htm, accessed on 15 May 2021.

\subsection{Research Questions and Organization}

Currently, the usage of social media has attracted intensive interest from academia and has become a hot research topic [25-27]. Most focus has been on popular social networking applications, e.g., Twitter and Facebook (abroad), Weibo and Wechat (in China). Social media applications have become convenient and efficient tools for relatedness, which provide happiness and well-being in a mobile world for emerging adults [28]. However, due to the multifaceted influence of social media on people's self-views and interpersonal relationships, previous researchers have indicated that the usage of smartphones and social media may cause cyberbullying, violence and anxiety etc., which has led to the increase in mental distress, self-injurious behavior and suicide, especially in youth [29-31]. The high proportions of youth engaged in frequent smartphone usage and media multitasking have much of their time occupied, as well as chronic sleep deprivation, which incurs negative effects on cognitive control, academic performance and socio-emotional functioning [32]. Wood et al. pointed out that social media has a positive impact upon loneliness, intimacy and relationship maintenance for youth, while it also has a negative impact through reckless behaviors [33]. Booker et al. suggested that gender differences impact the relationship between interacting on social media and well-being among youth [34]. Toma et al. revealed that sharing positive news, active postings and participation in online discussion groups has positive repercussions on youth well-being while cyberbullying and social comparisons with peers have negative repercussions [35]. Researchers found that social media usage may influence the intentions and behaviors of consuming [36], health education and promotion [37], pursuing employment [38], traveling [39], etc. Thus, we conducted 
social media research on intentions and perspectives to find the impact of anonymous social applications.

However, in the subcategory of social media, few studies have been concentrated on the usage of anonymous social applications. Soul has leapt to the top of anonymous social applications in China in just five years, which becomes the spotlight of academia and industry. By using quantitative methods, the study of usage intentions and behavior will provide the guidance for users to use ASM applications correctly and help create a healthy social environment [40]. Moreover, the behavior of generations are different and many factors will influence their decision-making [41]. In this paper, we aim to quantify user intentions for Soul app and try to address the following research questions (RQs):

- RQ 1: How do influencing factors affect user intentions to use Soul app?

- $\quad \mathrm{RQ} 2$ 2: What are the characteristics of user intentions among Soul users?

The structure of this paper is presented as follows: Section 2 presents our literature review about existing anonymous social applications. Section 3 presents the proposed theoretical model and then describes the hypotheses among each construct. Section 4 and Section 5 present the research methods and results of the data analysis, including reliability and validity measurements, hypothesis testing and prediction effects. Section 6 discusses the main findings and summarize insights from the analytical results. Finally, Section 7 concludes this paper.

\section{Literature Review}

Originally, studies of anonymity are derived from the fields of computer science and network security. Bernstein et al. proposed privacy protection strategies and solutions based on anonymous online transactions [42]. Douglass et al. identified and illustrated processes and elements to the emergence of "self" in on-line chat environments through grounded theory, indicating the emerges of "Cyberself" [43]. Connolly et al. conducted a study on the effects of anonymity and evaluative tone based on Computer Mediated Communication Groups [44]. Claessens et al. propose strategies to address anonymous communication on the Internet, based on its characteristics and different degrees of anonymity [45]. Nissenbaum et al. conducted a qualitative study on anonymity and explored whether anonymity should be protected in the electronic age [46]. The research on online anonymity in this period is mainly related to depersonalization, self-presentation, privacy and security and network problems.

In the study of early anonymous social products, Rafaeli et al. conducted research on BBS users' discussion topics, usage motives, etc., exploring the media characteristics of BBS [47]. Chou et al. used BBS as an example to study the Internet addiction phenomenon, usage behavior and pleasure of use [48]. Kou et al. studied different types of reply networks and constructed reply networks for various boards in BBS to connect users with the same interests [49]. Morrell et al. used ELDERCOMN as an example to explore how to train older people (60+ years old) to execute computer programs [50]. Pena-Shaff et al. studied the communication patterns and knowledge construction processes among BBS student users and showed the knowledge construction process was mainly characterized by clarification, elaboration and explanation, with less dialogical interactions in this process [51]. Since there were few relevant applications in the early stages of social media development, the research objects in this period were relatively limited, and most of them focused on BBS, deriving the expansion of various aspects such as nature, topics, usage behavior and usage motivation.

Web 2.0 has greatly enriched the functions and applications of social media, which promote the diversified development of anonymous social products. Research on anonymous social networking sites and applications have emerged. Bernstein et al. conducted a text analysis of 4chan, studied online ephemerality, anonymity and identity signals and found that "/b/" allows respondent users to establish status [42]. Hosseinmardi et al. studied negative user behaviors which have led to cases of cyberbullying and suicide on Ask.fm by exploring the occurrence of negative words [52]. As for the LBS campus application 
"Yik Yak", McKenzie et al. conducted a comparative analysis on Twitter and Yik Yak to find the differences with respect to themes and readability. They suggested that Yik Yak creates a distinct community with anonymity and visibility scope [53]. Northcut et al. conducted quantitative studies discussing the impact of anonymous posted content and coded them as Shock, Joke, Inquire and Emote [54]. Wang et al. explored user behavior for Whisper by analyzing the characteristics of anonymous social app users in post contents and usage frequency perspectives [55]. Sharon et al. interviewed Secret app users and found good approaches to study complex usage, attitudes and perceptions [56]. With the diversified development of anonymous social applications and the influx of young users, related research will be more abundant and comprehensive in the future.

\section{Theoretical Model and Hypotheses}

\subsection{Technology Acceptance Model}

The technology acceptance model (TAM) [57] has been widely utilized to explain users' acceptance behavior. The usage intentions of information systems are initially determined by attitudes, and influenced by the constructs of perceived usefulness and ease of use. The major extensions of TAM include TAM 2 [58], unified theory of acceptance and use of technology (UTAUT) [59], and TAM 3 [60]. TAM 2 explains perceived usefulness and intention to use from the perspectives of social influence and cognitive instrumental processes, by introducing new constructs of subjective norms, image, job relevance and output quality. UTAUT introduced the constructs of effort expectancy, performance expectancy, social influence and facilitation conditions through the comparative measurement. TAM 3 studied the determinants of individual adoption and usage by introducing the influence of individual differences and system characteristics, e.g., computer self-efficacy \& anxiety, perceptions of external control, etc., which can support decision-making on information system implementation.

\subsection{Research Model and Hypotheses}

In this paper, we aim to investigate the usage intentions and their influencing factors among Soul app users. The proposed conceptual model consists of Perceived Usefulness (PU), Perceived Ease of Use (PEOU), Perceived Anonymity (PA), Perceived Privacy Riskiness (PPR), Subjective Norms (SN), Emotional Attachments (EA), Perceived Interactivity (PI) and User Intention (UI). The definitions of each construct are given in Table 1.

In studies of individual acceptance research, the concept of intention to use derives from behavioral intention, which refers to an individual's decision to engage in a particular behavior based on expectations of the outcomes from the behavior. The intention to use reflects the extent to which an individual is willing to accept and use the particular technology. In the theory of reasoned action Model, behavioral intention is influenced by attitude [61], and TAM inherits this view by arguing that people's use of IT is influenced by behavioral intention, which is determined by a combination of attitude toward using and perceived usefulness, with attitude toward using determined by perceived usefulness and ease of use. The intention to use is jointly determined by perceived usefulness and ease of use. A glance at use has been found to be a reliable predictor of actual use [62]. We therefore considered intention to use as an outcome variable. 
Table 1. Definitions of constructs.

\begin{tabular}{cll}
\hline Construct & \multicolumn{1}{c}{ Definition } & \multicolumn{1}{c}{ Source } \\
\hline PU & $\begin{array}{l}\text { The degree to which users find anonymous } \\
\text { social apps are useful for their work and life. }\end{array}$ & Davis, 1989 [63] \\
\hline PEOU & $\begin{array}{l}\text { The degree to which users think it is effort- } \\
\text { less to use anonymous social apps. }\end{array}$ & Davis, 1989 [63] \\
\hline PA & $\begin{array}{l}\text { The psychological perception of users about } \\
\text { the anonymity of their identity during the use } \\
\text { of anonymous social apps. }\end{array}$ & Hite et al., 2014 [64] \\
\hline PPR & $\begin{array}{l}\text { The psychological perception of users about } \\
\text { the degree to which anonymous social apps } \\
\text { protect personal privacy information. }\end{array}$ & Dinev et al., 2006 [65] \\
\hline SN & $\begin{array}{l}\text { The degree to which users think that } \\
\text { important people believe they should use } \\
\text { anonymous social apps. }\end{array}$ & Timmermans et al., 2017 [66]; \\
\hline EA & $\begin{array}{l}\text { User perceptions of seeking emotional } \\
\text { relationships, venting emotions and obtaining } \\
\text { solace in the process of using anonymous social } \\
\text { apps. }\end{array}$ & $\begin{array}{l}\text { Sumternet et al., 2017 [67]; } \\
\text { Ma et al., 2014 [68] }\end{array}$ \\
\hline PI & $\begin{array}{l}\text { The degree to which users perceive the } \\
\text { interactivity of the system during the use of } \\
\text { anonymous social apps. }\end{array}$ & $\begin{array}{l}\text { Tu et al., 2002 [69]; } \\
\text { Rauniar et al., 2014; [70] }\end{array}$ \\
\hline UI & $\begin{array}{l}\text { The degree to which the users would like to } \\
\text { revisit ASM. }\end{array}$ & Venkatesh et al., 2000 [58] \\
\hline
\end{tabular}

\subsubsection{Perceived Usefulness and Perceived Ease of Use}

Perceived usefulness is derived from the definition of "useful" [63]. People often choose to use a particular media outlet to satisfy their own needs depending on usefulness [71]. Combined with uses and gratifications theory, the definition of perceived usefulness is extended from "work context" to "work context + life context".

Perceived ease of use is another important factor that influences people's behavior towards information systems [63]. Applications that are simpler and easier to use are more likely to be accepted by users [72]. Thus, user intentions for particular applications will be enhanced.

Salloum et al. found that PU and PEOU had significant positive effects on usage intention for online learning systems [73]. Dumpit et al. explored the intention to use Youtube among college students and found that PU and PEOU were very important positive influences [74]. Rauniar et al. studied Facebook individual adoption behavior and found that both constructs have significant influence on Facebook users [70]. Pinho et al. found that PU and PEOU influenced usage intention and behavior [75]. We hypothesize:

Hypothesis 1 (H1). PU has significant positive effects on UI for Soul users.

Hypothesis 2 (H2). PEOU has significant positive effects on UI for Soul users.

\subsubsection{Perceived Anonymity and Perceived Privacy Riskiness}

Anonymity is considered to be the inability of others to discover identify [11]. Rains et al. defines it as the degree of uncertainty about the source of information as perceived by the communicator [76]. Nevertheless, there exists technical anonymity and social anonymity [77]. The former refers to the removal of all identifying information (e.g., names) of other people when exchanging material or chatting online. The latter refers to the perception of individuals as unidentifiable via the Internet. The individual perceives to be anonymous to others. Currently, Internet service providers collect privacy data among 
users (e.g., consumers, content generators, netizen, etc.) for commercial purposes [78]. As a result, all social behaviors performed on social media are at risk of privacy breach. Considering online anonymity, privacy risk perception refers to a user's perception of the likelihood that an Internet vendor will attempt to protect confidential personal information for inappropriate use or disclosure [79]. The user's perception of privacy risk will affect the intention to use.

Users' desire for anonymous expression has given rise to various anonymous social platforms [14]. Users' motivations to seek anonymous environments is influenced by attitudes, technical barriers, and personal preferences [80]. Thus, they are more likely to use ASM by joining special interest groups to share or exchange help and support [81].

Perceived privacy risk is related to user intention. Dinev et al. found that users' perceived online privacy risk had an impact on intention to use by affecting user trust [65]. Hansen et al. found that an increase in perceived risk reduces the consumers' propensity to take risks, which significantly affects behavioral intentions in their study of consumers' social media usage behavior in transactions [82]. Wang et al. studied LBS usage intentions and found that perceived trust and perceived riskiness are negatively related. Perceived riskiness had a significant negative impact on user intentions [83]. Yun et al. used risky shift phenomenon to explain the privacy concerns of LBS application users, suggesting that an increase in privacy concerns would reduce user intention to use [84]. Henry et al. [85] found that user perceptions of the online privacy of Reddit is related to perceived anonymity. Therefore, we hypothesize:

Hypothesis 3 (H3). PPR has a significant negative effect on UI for Soul users.

Hypothesis 4 (H4). PA has a significant negative effect on PPR for Soul users.

\subsubsection{Subjective Norms}

Subjective norms are the perception of related groups or individuals (e.g., family members, friends and peers) and may influence a person's behavioral performance, which is an important factor to influence behavioral intentions [86]. Venkatesh et al. revealed the positive association between subjective norms and PU and intention to use [60]. Timmermans et al. [66] found that peer pressure and belongingness were the main usage motivations of Tinder users. Kim et al. [87] found that subjective norms of Facebook users were influenced by online interpersonal relationships and positively correlated with behavioral intention to like page ads. Arpaci [88] found that subjective norms were significantly related to users' social media postings. Thus, we hypothesize:

Hypothesis 5 (H5). SN have a significant positive effect on PU for Soul users.

Hypothesis 6 (H6). SN have a significant positive effect on UI for Soul users.

\subsubsection{Emotional Attachments}

Emotional attachment is an influential factor in mass communication, especially for the audience's choice of media. Use and gratification theory indicate that media usage aims to satisfy users' needs [89] and is widely adapted in the study of user behavior [90-92]. This shows the fact that media usage behavior is regarded as motivating and active [93]. As a branch of social media, ASM apps intend to meet the multiple needs of users, e.g., seeking emotions and new relationships, gaining attachments and entertainment, venting their emotions and sharing their lives [94].

In ASM apps, seeking emotional attachments is one of the main motivations of users $[67,95]$. Brandtzaeg et al. found that establishing emotional relationships and attachments are key motivations of using anonymous social networking sites [96]. Sumter et al. found that the motivations of users for the dating app Tinder included love seeking and time killing [67]. Timmermans et al. proposed a Tinder Motivation Scale (TMS), including seeking emotional relationships and entertainment [66]. VanMeter et al. applied Attach- 
ment Theory to social media, and found that attachment is a key predictor of meaningful social media behaviors [97]. Kowalczyk et al. revealed that emotional attachment positively influenced the outcomes of consumer behaviors [98]. Xu et al. found that attachment and social media usage for the acquisition of environmental information have positive relations with pro-environmental behaviors [99]. We hypothesize:

Hypothesis 7 (H7). EA have a significant positive effect on PU for Soul users.

Hypothesis 8 (H8). EA have a significant positive effect on UI for Soul users.

\subsubsection{Perceived Interactivity}

The conception of interactivity has been widely used in fields of computer science [100,101], advertising [102], marketing [103], education [104], etc. Interactivity can be increased from message and participant dimensions, e.g., flexible time of communication and easy control with response [105]. Therein, the studies of perception interactivity are consistently concentrated [106].

$\mathrm{Xu}$ et al. found that a higher PI increases Wechat user intentions for online interactions [107]. Lee et al. showed that PI is positively related to continuance usage intention and the willingness to exchange messages on animations, comics and games (ACG) of social media sites [108]. Abdullah et al. argued that perceived website interactivity influences the PEOU of the online booking [109]. Tu et al. found PI has a significant positive effect on the students' intentions and behavior in online class systems [69]. As instant messaging applications, ASM apps tend to develop interpersonal links based on weak relationships, unlike the strong relationship links of acquaintance social media. The higher sense of perceived interactivity will bring better experiences for users. Thus, we hypothesize:

Hypothesis 9 (H9). PI has a significant positive effect on PEOU for Soul users.

Hypothesis 10 (H10). PI has a significant positive effect on UI for Soul users.

In summary, the proposed conceptual model with hypotheses is presented in Figure 3.

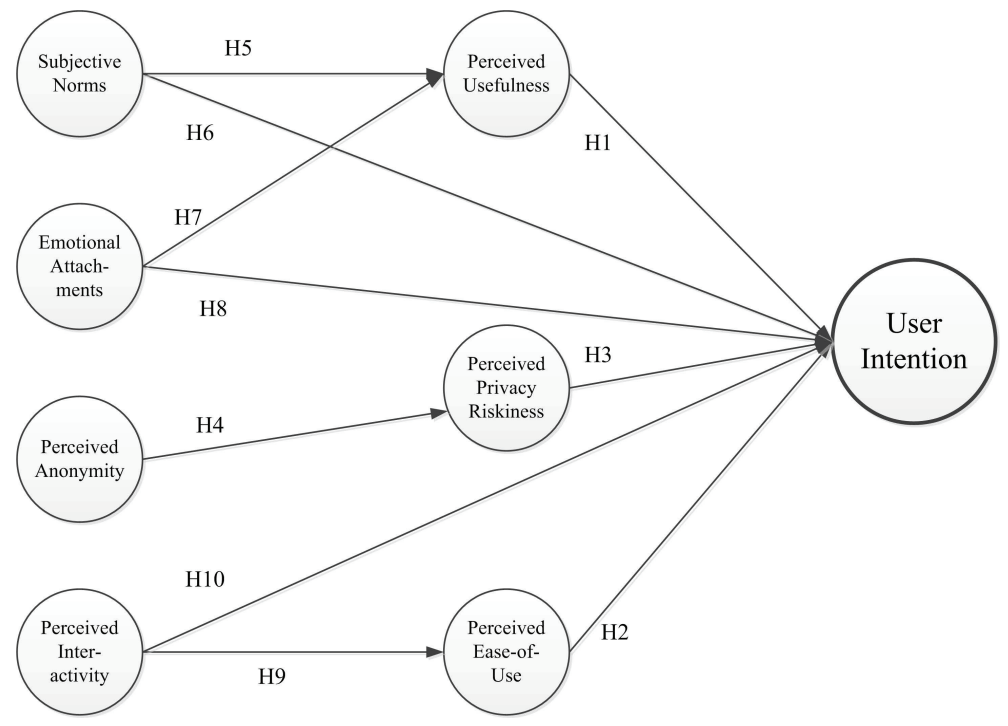

Figure 3. The proposed conceptual model. 


\section{Research Method}

\subsection{Data Collection}

The sample data for the empirical study were obtained via electronic questionnaire. We designed a Soul user intention and influencing factors questionnaire and distributed it from 30 June to 10 July 2021. It was distributed via three methods: (1) social media applications (e.g., Wechat and Soul), (2) offline distribution and (3) a survey platform (WJX, https://www.wjx.cn/) in China. The snowball sampling method was used. For the valid data, there were no missing values after checking.

In order to ensure the quality of questionnaires distributed by platform, we set (1) a requested filling time (within 150-1000 s) and (2) screening questions to ensure the participants were Soul users. Finally, a total of 611 questionnaires were returned and 419 valid questionnaires were obtained after screening. The recovery rate was $68.6 \%$. The sample size was greater than 10 times the largest number of structure paths $[110,111]$ and satisfied the basic needs to perform PLS-SEM via SmartPLS. We use a seven-point Likert scale to measure each item as shown in Table A2 of Appendix B for the respective construct. Participants score each item form " 1 " (strongly disagree) to " 7 " (strongly agree). A pre-test was also performed to carefully check the questions and then remove some questionnaire items (labeling * in Table A2). In terms of research ethics, all tools are acceptable in our university and the participants' individual privacy and the collected data are strictly protected.

\subsection{Demographic Characteristics}

For demographic characteristics, we conducted statistical analyses based on recovered data. As shown in Table 2, in terms of gender, the ratio of male to female participants in the survey was about 4:6. For the age distribution, the largest number of participants were concentrated in the $26-30$ year age group, which accounts for $44.6 \%$ of participants. There were no participants aged 40 years and above. In terms of education, the number of undergraduates ranked first, with $78 \%$ among all education levels. For the emotional status, the number of single people ranked first with $54.2 \%$, but the total number of married and in love accounted for about $50 \%$. For the usage behavior, $89.3 \%$ of the participants used the Soul app for less than 3 years. In terms of frequency of use, the percentage of people who use Soul every day were $45.6 \%$, slightly less than the percentage of infrequent users (54.4\%); while $90.2 \%$ of people spend 80 min or less on average per login. For the regional distribution, the participants came from 30 provinces, municipalities and autonomous regions in China. Therein, the participants from Guangdong, Beijing and Shanghai ranked as the top three places, which accounted for $17.7 \%, 12.6 \%$ and $7.4 \%$, respectively. According to the economic development level in China, four major regions, namely the eastern, central, western and northeastern regions are divided. Participants in the eastern region accounted for $59.5 \%$ (including 13 provinces and districts such as Beijing, Shanghai, Guangdong and Tianjin), $16.7 \%$ were from the central region (including 6 provinces and districts such as Shanxi, Henan and Hubei), 20.5\% were from the western region (including 12 provinces and districts such as Chongqing, Sichuan and Shanxi). The proportion of participants from the northeast region (including Heilongjiang, Jilin and Liaoning provinces) was 3.3\%. The regional distribution shows that users are mainly concentrated in the eastern region, and decrease from east to west. 
Table 2. The demographic characteristics $(\mathrm{N}=419)$.

\begin{tabular}{|c|c|c|c|}
\hline Characteristic & Category & Frequency & Percentage \\
\hline \multirow{2}{*}{ Gender } & Male & 166 & 39.6 \\
\hline & Female & 253 & 60.4 \\
\hline \multirow{5}{*}{ Age } & 18 years old and below & 2 & 0.5 \\
\hline & $18-25$ years old & 179 & 42.7 \\
\hline & $26-30$ years old & 187 & 44.6 \\
\hline & $31-40$ years old & 51 & 12.2 \\
\hline & Over 40 years old & 0 & 0.0 \\
\hline \multirow{5}{*}{ Education } & Junior high school and below & 3 & 0.7 \\
\hline & High School & 6 & 1.4 \\
\hline & College & 37 & 8.9 \\
\hline & University undergraduate & 327 & 78.0 \\
\hline & Master's degree and above & 46 & 11.0 \\
\hline \multirow{4}{*}{ Marital Status } & Single & 227 & 54.2 \\
\hline & In love & 75 & 17.9 \\
\hline & Married & 114 & 27.2 \\
\hline & Divorced & 3 & 0.7 \\
\hline \multirow{3}{*}{ Use time } & 1 year and below & 106 & 25.3 \\
\hline & $1-3$ years & 268 & 64.0 \\
\hline & $3-5$ years & 45 & 10.7 \\
\hline \multirow{5}{*}{ Frequency of use } & 1 time every few weeks & 36 & 8.6 \\
\hline & 1 time per week & 55 & 13.1 \\
\hline & 1 time every $2-3$ days & 137 & 32.7 \\
\hline & 1-3 times a day & 159 & 38.0 \\
\hline & More than 3 times a day & 32 & 7.6 \\
\hline \multirow{4}{*}{ Average time of use } & 40 min or less per session & 175 & 41.7 \\
\hline & $40-80 \mathrm{~min}$ & 199 & 47.5 \\
\hline & $80-120 \mathrm{~min}$ & 30 & 7.2 \\
\hline & $120 \mathrm{~min}$ or more & 15 & 3.6 \\
\hline
\end{tabular}

\section{Data Analysis}

\subsection{Measurement Model}

In this paper, we use the partial least squares (PLS)-SEM method via SmartPLS 3 to analyze the measurement model. Compared with other softwares (e.g., LISREL, Amos), PLS-SEM requires relatively fewer measurement scales and sample sizes and is good at prediction [112]. The assessment model was examined by a PLS-algorithm (maximum iterations 1000 , stop criterion $10^{-7}$ ) to measure indicator reliability, i.e., factor loading, which is suggested to be larger than 0.5 and preferably greater than 0.7 [113]. Consistency reliability consists of Cronbach's $\alpha$ and Composite Reliability (CR), which should be at least 0.6 [114] and prefarably above 0.7 [115], respectively. Convergent validity is tested by the average variance extracted (AVE) with the threshold of above 0.5 [116], which means that the construct can explain above $50 \%$ variance of its indicators averagely. Discriminate validity is tested by the Fornell-Larcker criterion. The square root of the AVE values need to be higher than the latent variable correlations [117].

As shown in Table 3, factor loading of items except PI4 all exceed 0.7. The item PI4 is just below 0.7 (0.694) but had no significant harm for internal consistency. The values of AVE for each construct ranged from 0.563 to 0.753 , which are all greater than 0.5 . The results of Cronbach's $\alpha$ ranged from 0.610 to 0.890 and all exceed 0.6, which is acceptable. CR ranged from 0.794 to 0.924 , which are larger than 0.7 . Furthermore, discriminate validity can check the diagonal coefficient in Table 4, which show that the square root of each construct AVE is bigger than its highest correlation with other constructs. This means that the constructs differ from each other. In conclusion, we can see that the reliability and validity assessments for each construct are satisfactory. 
Table 3. Results of reliability and validity.

\begin{tabular}{|c|c|c|c|c|c|}
\hline \multirow[b]{2}{*}{ Construct } & \multirow[b]{2}{*}{ Item } & \multirow{2}{*}{$\begin{array}{c}\begin{array}{c}\text { Indicator } \\
\text { Reliability }\end{array} \\
\begin{array}{c}\text { Factor } \\
\text { Loadings }\end{array}\end{array}$} & \multirow{2}{*}{$\begin{array}{c}\begin{array}{c}\text { Convergent } \\
\text { Validity }\end{array} \\
\text { AVE }\end{array}$} & \multicolumn{2}{|c|}{ Consistency Reliability } \\
\hline & & & & $\begin{array}{c}\text { Cronbach's } \\
\text { Alpha }\end{array}$ & CR \\
\hline \multirow{3}{*}{ EA } & EA1 & 0.811 & \multirow{3}{*}{0.563} & \multirow{3}{*}{0.610} & \multirow{4}{*}{0.794} \\
\hline & EA2 & 0.722 & & & \\
\hline & EA5 & 0.714 & & & \\
\hline \multirow{3}{*}{ PA } & PA3 & 0.829 & \multirow{3}{*}{0.711} & \multirow{3}{*}{0.797} & \\
\hline & PA4 & 0.864 & & & \multirow[t]{3}{*}{0.881} \\
\hline & PA5 & 0.836 & & & \\
\hline \multirow{3}{*}{ PEOU } & PEOU3 & 0.807 & \multirow{3}{*}{0.592} & \multirow{3}{*}{0.654} & \\
\hline & PEOU4 & 0.730 & & & \multirow[t]{2}{*}{0.813} \\
\hline & PEOU5 & 0.768 & & & \\
\hline \multirow{4}{*}{ PI } & PI2 & 0.782 & \multirow{3}{*}{0.599} & \multirow{3}{*}{0.671} & \multirow{3}{*}{0.817} \\
\hline & PI3 & 0.838 & & & \\
\hline & PI4 & 0.694 & & & \\
\hline & PPR1 & 0.848 & \multirow{4}{*}{0.753} & \multirow{4}{*}{0.890} & \multirow{4}{*}{0.924} \\
\hline \multirow{3}{*}{ PPR } & PPR2 & 0.895 & & & \\
\hline & PPR3 & 0.859 & & & \\
\hline & PPR4 & 0.867 & & & \\
\hline \multirow{4}{*}{ PU } & PU1 & 0.803 & \multirow{5}{*}{0.642} & \multirow{5}{*}{0.814} & \multirow{4}{*}{0.877} \\
\hline & PU3 & 0.789 & & & \\
\hline & PU4 & 0.809 & & & \\
\hline & PU5 & 0.803 & & & \\
\hline \multirow{4}{*}{ SN } & SN1 & 0.841 & & & \\
\hline & SN2 & 0.823 & \multirow{3}{*}{0.659} & & \\
\hline & SN3 & 0.788 & & 0.830 & 0.885 \\
\hline & SN4 & 0.795 & & & \\
\hline & UI1 & 0.837 & & & \\
\hline & UI2 & 0.714 & & & \\
\hline UI & UI3 & 0.721 & 0.590 & 0.825 & 0.878 \\
\hline & UI4 & 0.729 & & & \\
\hline & UI5 & 0.831 & & & \\
\hline
\end{tabular}

Table 4. Discriminant validity (Fornell-Larcker criterion).

\begin{tabular}{ccccccccc}
\hline & EA & PA & PEOU & PI & PPR & PU & SN & UI \\
\hline EA & $\mathbf{0 . 7 5 0}$ & & & & & & & \\
PA & 0.402 & $\mathbf{0 . 8 4 3}$ & & & & & & \\
PEOU & 0.362 & 0.333 & $\mathbf{0 . 7 6 9}$ & & & & & \\
PI & 0.436 & 0.396 & 0.464 & $\mathbf{0 . 7 7 4}$ & & & & \\
PPR & -0.241 & -0.400 & -0.129 & -0.219 & $\mathbf{0 . 8 6 7}$ & & & \\
PU & 0.660 & 0.384 & 0.376 & 0.439 & -0.251 & $\mathbf{0 . 8 0 1}$ & & \\
SN & 0.582 & 0.335 & 0.294 & 0.399 & -0.242 & 0.607 & $\mathbf{0 . 8 1 2}$ & \\
UI & 0.705 & 0.433 & 0.449 & 0.500 & -0.284 & 0.719 & 0.548 & $\mathbf{0 . 7 6 8}$ \\
\hline
\end{tabular}

\subsection{Structural Equation Model}

To examine the hypothesized effects according to the results of the measurement model, bootstrapping with 5000 samples and two tailed tests (significance level $=5 \%$ ) were conducted to obtain the path coefficients and significance level. The $R^{2}$ of the dependent constructs were calculated [118]. The overview of the direct effects structural models is shown in Figure 4.

As presented in Table 5, the hypotheses cover all constructs of the model. From the path coefficient, we can see that PU $(\beta=0.366, p<0.001)$ and PEOU $(\beta=0.121, p<0.01)$ have significant positive influences on UI. PA has a significant negative effect on PPR $(\beta=-0.400, p<0.001)$. PPR has a significant negative effect on UI $(\beta=-0.063, p<0.05)$. For $\mathrm{SN}$, it has no significant effect on UI $(\beta=0.037, p>0.05)$. However, the indirect effect 
between SN and UI via PU $(\beta=0.123, p<0.001)$ was significantly positive. SN had a strongly positive effect on PU $(\beta=0.037, p<0.001)$. EA had a significant positive effect both on PU $(\beta=0.464, p<0.001)$ and UI $(\beta=0.335, p<0.001)$. PI had a significant positive effect on both PEOU $(\beta=0.464, p<0.001)$ and UI $(\beta=0.108, p<0.01)$. We can see that the $p$-values of the main hypotheses are supported except for H6. There exists indirect effects between SN and UI via PU.

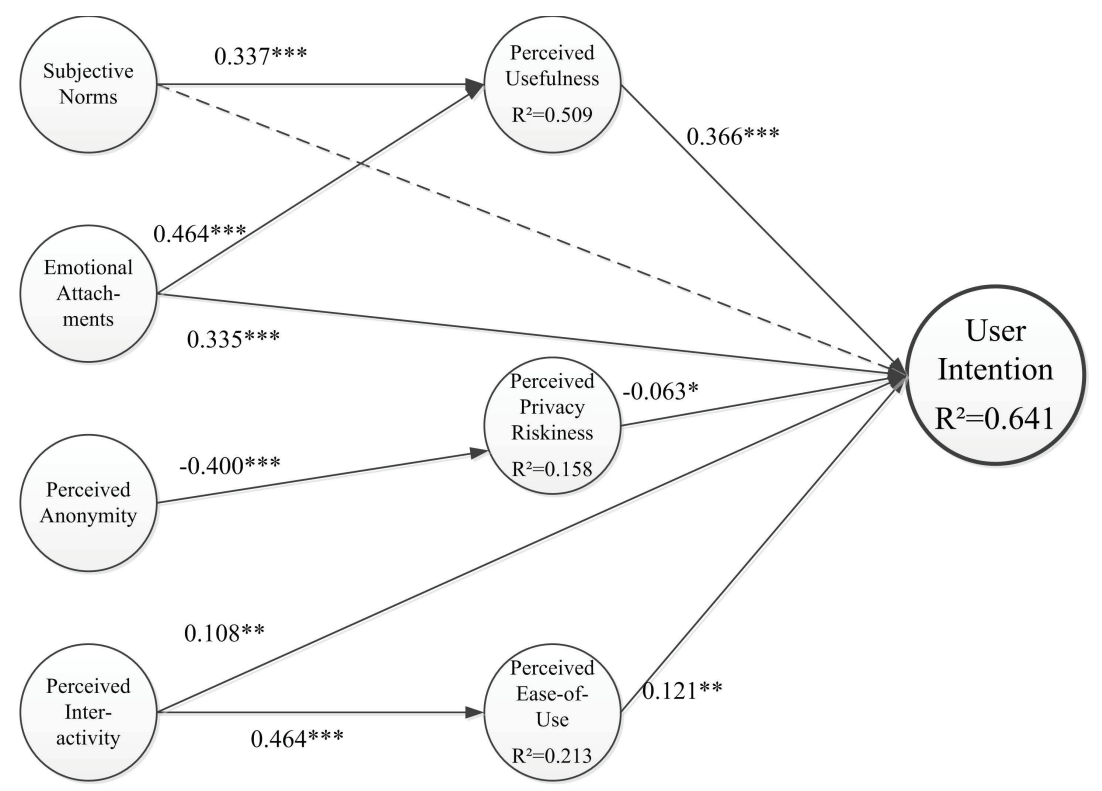

${ }^{*} \mathrm{p}<0.05 ; * * \mathrm{p}<0.01 ; * * * \mathrm{p}<0.001$. Dotted line represents insignificant path

Figure 4. Path coefficients.

Table 5. Structural model analyses (hypothesis testing).

\begin{tabular}{|c|c|c|c|c|c|c|}
\hline Hypotheses & Path & $\begin{array}{c}\text { Path } \\
\text { Coefficient } \\
(\beta)\end{array}$ & T-Statistics & $f^{2}$ & $p$-Value & Result \\
\hline $\mathrm{H} 1$ & PU ->UI & 0.366 & 5.855 & 0.177 & 0.000 & Supported \\
\hline $\mathrm{H} 2$ & PEOU ->UI & 0.121 & 2.993 & 0.031 & 0.003 & Supported \\
\hline H3 & PPR ->UI & -0.063 & 2.134 & 0.010 & 0.033 & Supported \\
\hline $\mathrm{H} 4$ & PA $->$ PPR & -0.400 & 10.723 & 0.191 & 0.000 & Supported \\
\hline H5 & $\mathrm{SN}->\mathrm{PU}$ & 0.337 & 6.452 & 0.154 & 0.000 & Supported \\
\hline H6 & $\mathrm{SN}->\mathrm{UI}$ & 0.037 & 0.833 & 0.002 & 0.405 & Not supported \\
\hline H7 & EA $->$ PU & 0.464 & 8.964 & 0.291 & 0.000 & Supported \\
\hline H8 & EA $->\mathrm{UI}$ & 0.335 & 6.424 & 0.156 & 0.000 & Supported \\
\hline H9 & PI ->PEOU & 0.464 & 10.944 & 0.274 & 0.000 & Supported \\
\hline H10 & PI ->UI & 0.108 & 2.613 & 0.022 & 0.009 & Supported \\
\hline \multicolumn{2}{|c|}{ Indirect Path } & $\begin{array}{c}\text { Path } \\
\text { coefficient }(\beta)\end{array}$ & \multicolumn{2}{|c|}{$\mathrm{Bca}[2.5 \%, 97.5 \%]$} & $\begin{array}{c}\mathrm{T}- \\
\text { Statistics }\end{array}$ & $p$-value \\
\hline \multicolumn{2}{|c|}{$\mathrm{SN}->\mathrm{PU}->\mathrm{UI}$} & 0.123 & \multicolumn{2}{|c|}{$[0,071,0.183]$} & 4.315 & 0.000 \\
\hline
\end{tabular}

As shown in Table 5, the effect size $f^{2}$ is used to measure the impact of variables on user intention. According to the thresholds of $f^{2}$ in [118], we find that EA, PEOU, PI and PU have a medium effect size $\left(f^{2}>0.15\right)$ on UI. EA and SN have medium effect size on PU. PA have a medium effect size on PPR. PI has a medium effect size on PEOU. PPR has a small effect size $\left(f^{2}>0.02\right)$ on UI.

In Table 6, we further evaluate the quality of the proposed PLS-SEM model via $R^{2}$ and $Q^{2}$, which can show the explanation and prediction effects. The $R^{2}$ provided by PLS algorithm indicated the proportion of variance explained by the proposed model 
with constructs [117]. Conclusively, the model predicted $64.1 \%$ of the variance in user intention. Subjective norms and emotional attachments accounted for $50.9 \%$ of variance in perceived usefulness. Perceived interactivity accounted for $21.5 \%$ of variation in ease of use for user intentions. Perceived anonymity accounted for $15.8 \%$ of the variance in perceived privacy risk. Additional criterion to assess the structural model is the predictive relevance $Q^{2}$, which can be measured in PLS blindfolding procedures. Values of $Q^{2}$ that are significantly non-zero indicate that the independent variables have predictive relevance for the dependent variable [118]. As a result, all of the four constructs have qualifying values.

Table 6. $R^{2}$ and $Q^{2}$.

\begin{tabular}{llll}
\hline Variables & $\boldsymbol{R}^{\mathbf{2}}$ & Adjusted $\boldsymbol{R}^{\mathbf{2}}$ & $Q^{\mathbf{2}}$ \\
\hline PEOU & 0.215 & 0.213 & 0.124 \\
PPR & 0.160 & 0.158 & 0.117 \\
PU & 0.511 & 0.509 & 0.322 \\
UI & 0.646 & 0.641 & 0.371 \\
\hline
\end{tabular}

\section{Discussion}

The findings indicate that the main part of the model and hypotheses we developed are supported by the results. Except for the subjective norms and perceived anonymity, the remaining five constructs with the direct paths on user intention are significant. The relationship between SN $\rightarrow$ PU and PA $\rightarrow$ PPR are supported as indirect influences on user intentions. Therefore, RQ 1 is answered in the hypothesis development and model analysis. The research also demonstrates that the proposed model for Soul usage intention provides research clues. Our hypotheses predicted that PU and PEOU have significant positive effects on UI. The greater the user's PU and PEOU, the more likely their intention to use the Soul app. Moreover, PU by using the Soul app will tend to satisfy users' needs during their spare time.

EA and PI show significant effects not only on UI but also on PU and PEOU, respectively. The results indicate that on the one hand, EA is an essential aspect of the PU of Soul users. The Soul users seeking relationships and venting negative emotions in anonymous ways will get health-benefits [119]. On the other hand, PI positively influences PEOU and UI by means of user-friendly system characteristics, attractive interface features and functions.

Contrary to a previous study [58], the direct effect of SN on UI was not significant. However, SN can indirectly affect UI by the mediator PU. From this finding, we can see that the opinions of important people around users have little effect on Soul UI to use. The reason can be summarized from two aspects: First, as the dominant age group among Soul users, the youth from Generation $\mathrm{Z}$ would like to learn everything on their own instead of following trends [120]. Second, users experienced social media fatigue in friend circles [121] and did not want to mix their circles of acquaintances with unconnected strangers known via ASM apps. This means that ASM becomes an independent outlet for the youth users to enjoin themselves.

In terms of PA and PPR, the results confirm that PA has a negative effect on PPR, which also shows negative relations with UI. The reason is obvious that hiding identification can protect users' privacy information. Therefore, risk of privacy leakage will be lower, which contributes to UI more continuously [122]. On the one hand, this somewhat emphasizes the key role of perceived privacy riskiness on usage intention, which is consistent with the fact that internet users' awareness of privacy risks is increasing. On the other hand, it also implies that users do not use anonymous social apps just to pursue the novelty brought by anonymity, but more for their personal privacy concerns. However, the curiosity induced by anonymity is also one of the important factors triggering intention to use [123].

As shown in Table 7, in terms of user intention, we can see that the intention to use, propensity to use and willingness to continue use are all strong. The percentage of participants who scored "5"-“7" ("Agree"-“Strongly agree") on the five questions UI1- 
UI5 were $91.1 \%, 89 \%, 88.5 \%, 68 \%$ and $89.3 \%$, respectively. UI1 (32.9\% of participants scored "7") and UI5 (47.3\% of participants scored "7") suggest higher levels of usage intention currently and in the future. Given the variety of social media applications and the rapid iterations [124], Soul users have shown a high level of adherence to the application. The reason can be found in Soul's novel functions, instant product updates, stylistic designment, etc., which greatly satisfies the needs of users and answered RQ 2.

Table 7. User intention descriptive statistics of results $(\mathrm{N}=419)$.

\begin{tabular}{|c|c|c|c|c|c|c|c|c|c|c|}
\hline \multirow[b]{2}{*}{ Score } & \multicolumn{2}{|c|}{ UI1 } & \multicolumn{2}{|c|}{ UI2 } & \multicolumn{2}{|c|}{ UI3 } & \multicolumn{2}{|c|}{ UI4 } & \multicolumn{2}{|c|}{ UI5 } \\
\hline & Frequency & Ratio (\%) & Frequency & Ratio (\%) & Frequency & Ratio (\%) & Frequency & Ratio (\%) & Frequency & Ratio (\%) \\
\hline 1 & 0 & 0 & 2 & 0.5 & 1 & 0.2 & 9 & 2.1 & 3 & 0.7 \\
\hline 2 & 3 & 0.7 & 2 & 0.5 & 5 & 1.2 & 11 & 2.6 & 6 & 1.4 \\
\hline 3 & 10 & 2.4 & 13 & 3.1 & 13 & 3.1 & 41 & 9.8 & 9 & 2.1 \\
\hline 4 & 24 & 5.7 & 29 & 6.9 & 29 & 6.9 & 73 & 17.4 & 27 & 6.4 \\
\hline 5 & 96 & 22.9 & 72 & 17.2 & 108 & 25.8 & 111 & 26.5 & 61 & 14.6 \\
\hline 6 & 148 & 35.3 & 158 & 37.7 & 143 & 34.1 & 109 & 26.0 & 115 & 27.4 \\
\hline 7 & 138 & 32.9 & 143 & 34.1 & 120 & 28.6 & 65 & 15.5 & 198 & 47.3 \\
\hline Mean & \multicolumn{2}{|c|}{5.89} & \multicolumn{2}{|c|}{5.89} & \multicolumn{2}{|c|}{5.74} & \multicolumn{2}{|c|}{5.04} & \multicolumn{2}{|c|}{6.04} \\
\hline Median & \multicolumn{2}{|c|}{6.00} & \multicolumn{2}{|c|}{6.00} & \multicolumn{2}{|c|}{6.00} & \multicolumn{2}{|c|}{5.00} & \multicolumn{2}{|c|}{6.00} \\
\hline Variance & \multicolumn{2}{|c|}{1.106} & \multicolumn{2}{|c|}{1.257} & \multicolumn{2}{|c|}{1.285} & \multicolumn{2}{|c|}{2.030} & \multicolumn{2}{|c|}{1.479} \\
\hline
\end{tabular}

For each participant, the average score of UI (from UI 1 to UI 5 items) was calculated and tested the usage difference or relationship among the gender and martial status regarding the UI. As shown in Table 8 , for gender, the independent $t$-test was conducted and the analysis results revealed that there was no significant difference between male and female $(t(419)=0.468, p>0.05)$. Gender did not have an effect on UI. For martial status, the Pearson correlation coefficient $r=0.113<0.3$ was in agreement with the significant level of $0.05(p=0.021<0.05)$. It can been seen that the martial status had a weak correlation relationship with the UI.

Table 8. The gender and martial status for UI.

\begin{tabular}{lllll}
\hline Item & Group & Number & Mean & Sig. (Two-Tailed) \\
\hline \multirow{2}{*}{ Gender } & Male & 166 & 5.74 & 0.640 \\
& Female & 253 & 5.71 & \\
\multirow{4}{*}{ Martial status } & Single & 227 & 5.68 & \\
& In love & 75 & 5.43 & 0.021 \\
& Married & 114 & 5.97 & \\
& Divorced & 3 & 6.60 & \\
\hline
\end{tabular}

According to the "Medium and Long Term Youth Development Plan (2016-2025)" in China [125], the age of the youth group is defined as 14-35 years old. The age of Soul users overlaps with it. The results of our survey on Soul user behavior show that around $75 \%$ of users have been using Soul for more than a year, nearly half of the surveyed users log in to Soul every day and $7.6 \%$ even log in more than three times a day, in addition to which, more than half of the participants log in for more than 40 minutes each time. The result leads us to worry about the negative effects of anonymous social media on users' physical and mental health. When users spend too much time on social media, the beneficial functional properties will diminish and cause negative issues such as social media addiction [126]. In addition, inappropriate social media use can lead to psychological problems such as cyberbullying [127], internet violence [128] and depression [129]. Teenagers get satisfaction from using Soul, but they also face problems, especially in lack of self-control and judgement. Moreover, they will be more likely to develop bad usage behavior. Therefore, the use and social impact of anonymous social apps must be viewed with caution. 


\section{Limitations}

The limitations of this study are mainly summarized as follows: First, the number of Soul users recruited off-line is relatively small, compared to Wechat and other acquaintance social apps, some people who want to keep anonymous are reluctant to let others know that they are using Soul. As a result, online research users account for the majority of the sample. Although we set up a screening question (write down two or more matching functions/tags/topics etc. on Soul), the filling behavior of online users is not easy to observe. In future work, the off-line distribution and samples from middle \& western regions should be paid more attention to obtain more questionnaires. Second, the lack of long-term observations among Soul users. User responses are cross-sectional data, which present a snapshot of the situation. The data collection in this study may not determine the influence of the proposed variables on UI long term. Therefore, we should consider in-depth observation methods to validate and further extend the proposed model. Third, there is a lack of qualitative supporting research. We only conducted structural equation modeling tests on users' intention to use, and did not use qualitative research methods such as interviews as the supplement. The semi-structured interviews are considered to support the conclusions in further work.

\section{Conclusions}

In this paper, we have conducted quantitative research to investigate Soul users' intention from seven dimensions: perceived usefulness (PU), perceived ease of use (PEOU), perceived anonymity (PA), perceived privacy risk (PPR), subjective norms (SN), emotional attachments (EA) and perceived interactivity (PI). Except for SN, the remaining hypotheses we developed were in line with the prior works and supported by the results. The constructs of PU, PPR, PEOU, EA and PI have direct paths to user intention. We have found that when people select anonymous social media (ASM) apps, the factors of perceived usefulness and ease of use are considered as vital criteria. The stronger the usefulness and ease of use, the more willing users will be to adopt the app. Moreover, the functions, interface and system stability also have significant impacts on willingness to use. Although perceived anonymity does not directly affect user intention, it has a negative relationship with privacy risk. As mediation, the strength of perceived privacy risk will influence Soul users' intentions. Emotional attachments allows users to seek emotional relationships and build online secret spaces. Soul users, especially the youth, have higher levels of adherence and continuous usage intentions to express their emotions in an anonymous environment.

In terms of the implication of this study, the influencing factors of ASM and the characteristics of users have been revealed, which can provide insights into guidelines for ASM apps. Especially for the youth, ASM service providers should offer a healthy surfing atmosphere and positive topics among the anonymous online community.

Author Contributions: Conceptualization, Z.Y. and X.S.; methodology, Z.Y.; validation, Z.Y. and X.S.; formal analysis, Z.Y. and X.S.; investigation, Z.Y. and X.S.; writing-original draft preparation, Z.Y. and X.S.; writing-review and editing, Z.Y. and X.S.; visualization, Z.Y. and X.S.; supervision, Z.Y.; funding acquisition, Z.Y. All authors have read and agreed to the published version of the manuscript.

Funding: This research was funded by the First-class Discipline Incentive Plan of Shandong University for Media Science Project with grant number 2019MJ09; Key Research and Development Program of Shandong Province (Soft Science Project) with grant number 2020RKE27008; The Teaching Reform Project of Shandong University with grant number 2020XWKC012 and 2020Y029; The Laboratory Construction and Management Research Project of Shandong University with grant number SY20201101.

Institutional Review Board Statement: Not applicable.

Informed Consent Statement: Not applicable.

Data Availability Statement: Not applicable.

Conflicts of Interest: The authors declare no conflict of interest. 


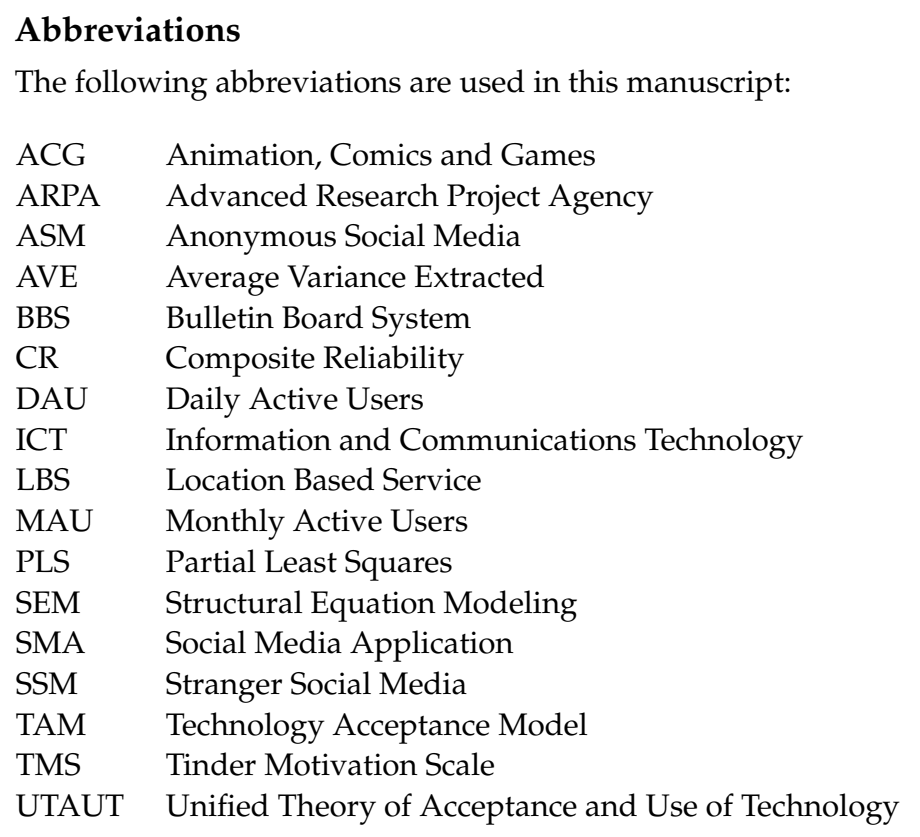




\section{Appendix A. The Representative Anonymous Social Applications}

Table A1. The representative anonymous social applications.

\begin{tabular}{|c|c|c|c|c|c|}
\hline Phase & Products & & Year & Country & Features/Functions \\
\hline \multirow{4}{*}{ Internet Era } & \multicolumn{2}{|l|}{ Usenet } & 1980 & Worldwide & $\begin{array}{l}\text { Distributed discussion Internet communication system available on } \\
\text { computers, users can read and post messages }\end{array}$ \\
\hline & \multirow{3}{*}{ Online Business Services } & Genie & 1985 & Worldwide & Business services, online text game communities \\
\hline & & CompuServe & 1969 & America & Online chat systems, topic communities \\
\hline & & Electronic mailing List & 1975 & Worldwide & Email list system \\
\hline \multirow{6}{*}{ Web1.0 Era } & \multirow{2}{*}{ Virtual Community } & BBS & $1980 \mathrm{~s}$ & Worldwide & $\begin{array}{l}\text { Bulletin boards, classified forums, news reading, software downloads and } \\
\text { uploads, games, user online conversations, etc. }\end{array}$ \\
\hline & & Internet forums & 1980s & Worldwide & Topic discussion, resource sharing \\
\hline & \multicolumn{2}{|l|}{ 2channel } & 1999 & Japan & Online community, Anonymous Posting \\
\hline & \multirow{2}{*}{ Website } & Match.com & 1993 & Worldwide & Online dating service \\
\hline & & 4chan & 2003 & Worldwide & Posting is ephemeral, image-based bulletin board \\
\hline & Blog & & 1994 & Worldwide & Online diary, posting and sharing \\
\hline \multirow{11}{*}{ Web2.0 Era } & Anonymous functions of social media & QQ mail "drift bottle" & 2010 & China & Anonymous "drift bottles" \\
\hline & \multirow{3}{*}{ Social networking site } & Ask.fm & 2010 & Latvia & Create personal profiles and send anonymous questions to each other \\
\hline & & Spring.me (Formspring) & 2009 & Worldwide & Quiz community \\
\hline & & Reddit & 2005 & America & Social news aggregation,web contents rating, discussion website \\
\hline & Social networking site & Sarahah & 2016 & Saudi Arabian & Send anonymous text messages, providing constructive feedback \\
\hline & \multirow{6}{*}{ Applications } & Whisper & 2012 & America & Post and share photo and video messages anonymously \\
\hline & & Secret & 2014 & America & \multirow{2}{*}{ Share information anonymously in users' circle of friends } \\
\hline & & Mimi & 2014 & China & \\
\hline & & After School & 2014 & America & Platform for teenage groups to express, share, and ask for help anonymously \\
\hline & & Yik Yak & 2013 & America & LBS-based anonymous social application used in campus \\
\hline & & Soul & 2016 & China & Anonymous social applicaton, focus on "soul" matching \\
\hline
\end{tabular}




\section{References}

1. Fuchs, C.; Hofkirchner, W.; Schafranek, M.; Raffl, C.; Sandoval, M.; Bichler, R. Theoretical foundations of the web: Cognition, communication, and co-operation: Towards an understanding of Web 1.0, 2.0, 3.0. Future Internet 2010, 2, 41-59. [CrossRef]

2. Mayfield, A. What Is Social Media. 2008. Available online: http://crmxchange.com/uploadedFiles/White_Papers/PDF/What_ is_Social_Media_iCrossing_ebook.pdf (accessed on 5 March 2021).

3. Carr, C.T.; Hayes, R.A. Social media: Defining, developing, and divining. Atl. J. Commun. 2015, $23,46-65$. 15456870.2015.972282. [CrossRef]

4. Kaplan, A.M.; Haenlein, M. Users of the world, unite! The challenges and opportunities of social media. Bus. Horizons 2010, 53, 59-68. [CrossRef]

5. Edosomwan, S.; Prakasan, S.K.; Kouame, D.; Watson, J.; Seymour, T. The history of social media and its impact on business. J. Appl. Manag. Entrep. 2011, 16, 79-91.

6. Digital 2021-We Are Social. Available online: https://wearesocial.com/digital-2021 (accessed on 5 March 2021).

7. Kietzmann, J.H.; Kristopher, H. Social media? Get serious! Understanding the functional building blocks of social media. Bus. Horizons 2011, 54, 241-251. [CrossRef]

8. China Internet Network Information Center. The 48th Statistical Report on the Development Status of the Internet in China. Available online: http:/ / www.cnnic.net.cn/hlwfzyj/hlwxzbg/hlwtjbg/202109/P020210915523670981527.pdf (accessed on 20 September 2021).

9. Kasakowskij, R.; Friedrich, N.; Fietkiewicz, K.J.; Stock, W.G. Anonymous and non-anonymous user behavior on social media: A case study of Jodel and Instagram. J. Inf. Sci. Theory Pract. 2018, 6, 25-36.

10. iiMedia Report. 2019 Q1 China Stranger Social Market Quarterly Monitoring Report. 2019. Available online: https://www. iimedia.cn/c400/64669.html (accessed on 16 September 2021).

11. Christopherson, K.M. The positive and negative implications of anonymity in Internet social interactions: "On the Internet, Nobody knows you're a dog". Comput. Hum. Behav. 2007, 23, 3038-3056. [CrossRef]

12. Walther, J.B. Computer-mediated communication. Commun. Res. 1996, 23, 3-43. [CrossRef]

13. Gupta, R.; Brooks, H. Using Social Media for Global Security; John Wiley \& Sons: Hoboken, NJ, USA, 2013 ; pp. 13-31.

14. Correa, D.; Silva, L.A.; Mondal, M.; Benevenuto, F.; Gummadi, K.P. The many shades of anonymity: Characterizing anonymous social media content. In Proceedings of the 9th Proceedings of the International AAAI Conference on Web and Social Media (ICWSM), Oxford, UK, 26-29 May 2015.

15. Bumgarner, B.A. You have been poked: Exploring the uses and gratifications of Facebook among emerging adults. First Monday 2007, 12. [CrossRef]

16. Blackwell, D.; Leaman, C.; Tramposch, R.; Osborne, C.; Liss, M. Extraversion, neuroticism, attachment style and fear of missing out as predictors of social media use and addiction. Personal. Individ. Differ. 2017, 116, 69-72. [CrossRef]

17. Bazarova, N.N.; Choi, Y.H. Self-disclosure in social media: Extending the functional approach to disclosure motivations and characteristics on social network sites. J. Commun. 2014, 64, 635-657. [CrossRef]

18. Vishwanath, A. Habitual Facebook use and its impact on getting deceived on social media. J. Comput. Mediat. Commun. 2015, 20, 83-98. [CrossRef]

19. Shieber, J. Whisper Launches New Tool to Automate Article Creation from Its User-Generated Content; TechCrunch: San Francisco, CA, USA, 2017. Available online: https://techcrunch.com/2017/03/13/it-started-with-a-whisper/ (accessed on 1 August 2021).

20. Werner Vermaak. What Is Web 3.0? Available online: https://coinmarketcap.com/alexandria/article/what-is-web-3-0 (accessed on 8 February 2021).

21. Furjan, M.T.; Tomičić-Pupek, K.; Pihir, I. Understanding digital transformation initiatives: Case studies analysis. Bus. Syst. Res. 2020, 11, 125-141. [CrossRef]

22. Bach, M.P.; Spremić, M.; Vugec, D.S. Integrating digital transformation strategies into firms: Values, routes and best practice examples. In Management and Technological Challenges in the Digital Age; Melo, P.N., Machado, C., Eds.; CRC Press: Boca Raton, FL, USA, 2018; pp. 107-128.

23. SevenMac Data. China App Store Ranking. 2021. Available online: https://www.qimai.cn/app/rank/appid/1032287195 / country/cn (accessed on 22 September 2021).

24. Form F-1. Available online: https://www.sec.gov/Archives/edgar/data/1832879/000119312521156430/d109555df1.htm (accessed on 15 May 2021).

25. Akar, E.; Mardikyan, S. Analyzing factors affecting users' behavior intention to use social media: Twitter case. Int. J. Bus. Soc. Sci. 2014, 11, 5 .

26. Zhang, X.; Ma, L.; Xu, B.; Xu, F. How social media usage affects employees' job satisfaction and turnover intention: An empirical study in China. Inf. Manag. 2019, 56, 103136. [CrossRef]

27. Li, H.; Li, L.; Gan, C.; Liu, Y.; Tan, C. W.; Deng, Z. Disentangling the factors driving users' continuance intention towards social media: A configurational perspective. Comput. Hum. Behav. 2018, 85, 175-182. [CrossRef]

28. Manago, A.M.; Vaughn, L. Social media, friendship, and happiness in the millennial generation. Friendsh. Happiness 2015, 187-206. [CrossRef]

29. Alonzo, R.; Hussain, J.; Stranges, S.; Anderson, K.K. Interplay between social media use, sleep quality, and mental health in youth: A systematic review. Sleep Med. Rev. 2020, 56, 101414. [CrossRef] [PubMed] 
30. Biernesser, C.; Sewall, C.J.; Brent, D.; Bear, T.; Mair, C.; Trauth, J. Social media use and deliberate self-harm among youth: A systematized narrative review. Child. Youth Serv. Rev. 2020, 116, 105054. [CrossRef]

31. Riehm, K.; Feder, K.; Tormohlen, K.; Crum, R.; Young, A.; Green, K.M.; Pacek, L.; Flair, L.N.; Mojtabai, R. Associations between time spent using social media and internalizing and externalizing problems among US youth. JAMA Psychiatry 2019, 76, 1-9. [CrossRef]

32. Abi-Jaoude, E.; Naylor, K.T.; Pignatiello, A. Smartphones, social media use and youth mental health. CMAJ 2020, 192 , E136-E141. [CrossRef]

33. Wood, M.A.; Bukowski, W.; Lis, E. The digital self: How social media serves as a setting that shapes youth's emotional experiences. Adolesc. Res. Rev. 2016, 1, 163-173. [CrossRef]

34. Booker, C.L.; Kelly, Y.J.; Sacker, A. Gender differences in the associations between age trends of social media interaction and well-being among 10-15 year olds in the UK. BMC Public Health 2018, 18, 1-12. [CrossRef]

35. Toma, C.L.; Chen, Y.A.; Olson, C.; Fan, T.; Brown, B.B. Youth social media use and well-being. In The International Encyclopedia of Media Psychology; Bulck, J., Ed.; John Wiley \& Sons: Hoboken, NJ, USA, 2020. [CrossRef]

36. Shi, N.P.; Ismail, S.N. Social media influences on purchase intention among youth in Malaysia. Res. Manag. Technol. Bus. 2021, 2, 259-272.

37. Chaoguang, H.; Feicheng, M.; Yifei, Q.; Yuchao, W. Exploring the determinants of health knowledge adoption in social media: An intention-behavior-gap perspective. Inf. Dev. 2018, 34, 346-363. [CrossRef]

38. Bowen, C.C.; Stevenor, B.A.; Davidson, S.G. How people perceive different types of social media screening and their behavioral intention to pursue employment. Comput. Hum. Behav. Rep. 2021, 3, 100089. [CrossRef]

39. Chavez, L.; Ruiz, C.; Currás, R.; Hernández, B. The role of travel motivations and social media use in consumer interactive behaviour: A uses and gratifications perspective. Sustainability 2020, 12, 8789. [CrossRef]

40. Abbas, J.; Aman, J.; Nurunnabi, M.; Bano, S. The impact of social media on learning behavior for sustainable education: Evidence of students from selected universities in Pakistan. Sustainability 2019, 11, 1683. [CrossRef]

41. Sosa, I.; Knežević, M. B.; Falat, M. What Influences decision making in online purchasing of bBooks in Generation X and Y? In Proceedings of the ENTRENOVA-ENTerprise REsearch InNOVAtion Conference, Rovinj, Croatia, 12-14 September 2019.

42. Bernstein, M.; Monroy-Hernndez, A.; Harry, D.; Andr, P.; Panovich, K.; Vargas, G. 4chan and /b/: An analysis of anonymity and ephemerality in a large online community. In Proceedings of the 15th International AAAI Conference on Web and Social Media (ICWSM), Barcelona, Spain, 17-21 July 2011; Volume 5.

43. Douglass, D.W.M. Cyberself: The emergence of self in on-line chat. Inf. Soc. 1997, 13, 375-397. [CrossRef]

44. Connolly, T.; Jessup, L.M.; Valacich, J.S. Effects of anonymity and evaluative tone on idea generation in computer-mediated groups. Manag. Sci. 1990, 36, 689-703. [CrossRef]

45. Claessens, J.; Preneel, B.; Vandewalle, J. Solutions for anonymous communication on the Internet. In Proceedings of the IEEE 33rd Annual 1999 International Carnahan Conference on Security Technology (ICCST), Montreal, QC, Canada, 5-7 October 1999; pp. 298-303. [CrossRef]

46. Nissenbaum, H. The meaning of anonymity in an information age. Inf. Soc. 1999, 15, 141-144. [CrossRef]

47. Rafaeli, S. The electronic bulletin board: A computer-driven mass medium. Soc. Sci. Micro Rev. 1984, 2, 123-136. [CrossRef]

48. Chou, C.; Chou, J.; Tyan, N.N. An exploratory study of Internet addiction, usage and communication pleasure: The Taiwan's case. Int. J. Educ. Telecommun. 1999, 5, 47-64.

49. Kou, Z.; Zhang, C. Reply networks on a bulletin board system. Phys. Rev. E 2003, 67, 036117.

50. Morrell, R.W.; Denise, C.P.; Christo, R. Effects of age and instructions on teaching older adults to use ELDERCOMM, An electronic bulletin board system. Educ. Gerontol. 2000, 26, 221-235. [CrossRef]

51. Pena-Shaff, J.B.; Nicholls, C. Analyzing student interactions and meaning construction in computer bulletin board discussions. Comput. Educ. 2004, 42, 243-265. [CrossRef]

52. Hosseinmardi, H.; Han, R.; Lv, Q.; Mishra, S.; Ghasemianlangroodi, A. Analyzing Negative User Behavior in a Semi-Anonymous Social Network. 2014. Available online: https://arxiv.org/abs/1404.3839v1 (accessed on 8 February 2021).

53. McKenzie, G.; Adams, B.; Janowicz, K. Of Oxen and Birds: Is Yik Yak a useful new data source in the geosocial zoo or just another Twitter? In Proceedings of the 8th ACM SIGSPATIAL International Workshop on Location-Based Social Networks, Bellevue, WA, USA, 3-6 November 2015; pp. 1-4. [CrossRef]

54. Northcut, K.M. Dark side or insight? Yik Yak and culture on campus. In Proceedings of the 2015 IEEE International Professional Communication Conference (IPCC), Limerick, Ireland, 12-15 July 2015; pp. 1-5. [CrossRef]

55. Wang, G.; Wang, B.; Wang, T.; Nika, A.; Zheng, H.; Zhao, B.Y. Whispers in the dark. In Proceedings of the 2014 Conference on Internet Measurement Conference, Vancouver, BC, Canada, 5-7 November 2014; pp. 137-150. [CrossRef]

56. Sharon, T.; John, N.A. Unpacking (the) secret: Anonymous social media and the impossibility of networked anonymity. New Media Soc. 2018, 20, 4177-4194. [CrossRef]

57. Davis, F.D. A technology acceptance model for empirically testing new end-user information systems: Theory and results. Mass. Inst. Technol. 1985. Available online: http:/ / dspace.mit.edu/handle/1721.1/15192 (accessed on 8 February 2021).

58. Venkatesh, V.; Davis, F.D. A theoretical extension of the technology acceptance model: Four longitudinal field studies. Manag. Sci. 2000, 46, 186-204. [CrossRef] 
59. Venkatesh, V.; Morris, M.G.; Davis, G.B.; Davis, F.D. User acceptance of information technology: Toward a unified view. Mis Q. 2003, 27, 425. [CrossRef]

60. Venkatesh, V.; Bala, H. Technology acceptance model 3 and a research agenda on interventions. Decis. Sci. 2008, 39, 273-315. [CrossRef]

61. Fishbein, M.; Ajzen, I. Predicting and Changing Behavior: The Reasoned Action Approach; Psychology Press, Taylor \& Francis: New York, NY, USA, 2011.

62. Ajzen, I. The theory of planned behavior. Organ. Behav. Hum. Decis. Process. 1991, 50, 179-211. [CrossRef]

63. Davis, F.D. Perceived usefulness, perceived ease of use, and user acceptance of information technology. MIS Q. 1989, 13, 319. [CrossRef]

64. Hite, D.M.; Voelker, T.; Robertson, A. Measuring perceived anonymity: The development of a context independent instrument. J. Methods Meas. Soc. Sci. 2014, 5, 22. [CrossRef]

65. Dinev, T.; Hart, P. An extended privacy calculus model for e-commerce transactions. Inf. Syst. Res. 2006, 17, 61-80. [CrossRef]

66. Timmermans, E.; De Caluwe, E. Development and validation of the Tinder Motives Scale (TMS). Comput. Hum. Behav. 2017, 70, 341-350. [CrossRef]

67. Sumter, S.R.; Vandenbosch, L.; Ligtenberg, L. Love me Tinder: Untangling emerging adults' motivations for using the dating application Tinder. Telemat. Inform. 2017, 34, 67-78. [CrossRef]

68. Ma, W.W.; Chan, A. Knowledge sharing and social media: Altruism, perceived online attachment motivation, and perceived online relationship commitment. Comput. Hum. Behav. 2014, 39, 51-58. [CrossRef]

69. Tu, C.H.; McIsaac, M. The relationship of social presence and interaction in online classes. Am. J. Distance Educ. 2002, 16, 131-150. [CrossRef]

70. Rauniar, R.; Rawski, G.; Yang, J.; Johnson, B. Technology acceptance model (TAM) and social media usage: An empirical study on Facebook. J. Enterp. Inf. Manag. 2014, 27, 6-30. [CrossRef]

71. Hajli, M.N. A study of the impact of social media on consumers. Int. J. Mark. Res. 2014, 56, 387-404. [CrossRef]

72. Venkatesh, V. Determinants of perceived ease of use: Integrating control, intrinsic motivation, and emotion into the technology acceptance model. Inf. Syst. Res. 2000, 11, 342-365. [CrossRef]

73. Salloum, S.A.; Al-Emran, M.; Habes, M.; Alghizzawi, M.; Ghani, M.A.; Shaalan, K. What impacts the acceptance of e-learning through social media: An empirical study. In Recent Advances in Technology Acceptance Models and Theories; Springer Nature: Cham, Switzerland, 2021; pp. 419-431. [CrossRef]

74. Dumpit, D.Z.; Fernandez, C.J. Analysis of the use of social media in Higher Education Institutions (HEIs) using the technology acceptance model. Int. J. Educ. Technol. High. Educ. 2017, 14, 1-16. [CrossRef]

75. Pinho, J.C.M.R.; Soares, A.M. Examining the technology acceptance model in the adoption of social networks. J. Res. Interact. Mark. 2011, 5, 116-129. [CrossRef]

76. Rains, S.A.; Scott, C.R. To identify or not to identify: A theoretical model of receiver responses to anonymous communication. Commun. Theory 2007, 17, 61-91. [CrossRef]

77. Hayne, S.C.; RICE, R.E. Attribution accuracy when using anonymity in group support systems. Int. J. -Hum.-Comput. Stud. 1997, 47, 429-452. [CrossRef]

78. Phelps, J.E.; D'Souza, G.; Nowak, G.J. Antecedents and consequences of consumer privacy concerns: An empirical investigation. J. Interact. Mark. 2001, 15, 2-17. [CrossRef]

79. Debatin, B.; Lovejoy, J.P.; Horn, A.K.; Hughes, B.N. Facebook and online privacy: Attitudes, behaviors, and unintended consequences. J. Comput. Mediat. Commun. 2009, 15, 83-108. [CrossRef]

80. Kang, R.; Dabbish, L.; Sutton, K. Strangers on your phone. In Proceedings of the 19th ACM Conference on Computer-Supported Cooperative Work \& Social Computing, San Francisco, CA, USA, 27 February-2 March 2016; pp. 359-370. [CrossRef]

81. Kang, R.; Brown, S.; Kiesler, S. Why do people seek anonymity on the internet? In Proceedings of the SIGCHI Conference on Human Factors in Computing Systems, Paris, France, 27 April-2 May 2013; pp. 2657-2666. [CrossRef]

82. Hansen, J.M.; Saridakis, G.; Benson, V. Risk, trust, and the interaction of perceived ease of use and behavioral control in predicting consumers' use of social media for transactions. Comput. Hum. Behav. 2018, 80, 197-206. [CrossRef]

83. Wang, E.S.T.; Lin, R.L. Perceived quality factors of location-based apps on trust, perceived privacy risk, and continuous usage intention. Behav. Inf. Technol. 2017, 36, 1-9. [CrossRef]

84. Yun, H.; Han, D.; Lee, C.C. Understanding the use of location-based service applications: Do privacy concerns matter? J. Electron. Commer. Res. 2013, 14, 215.

85. Triggs, A.H.; Mller, K.; Neumayer, C. Context collapse and anonymity among queer Reddit users. Neww Media Soc. $2021,23,5-21$. [CrossRef]

86. Fishbein, M. A Behavior theory approach to the relations between beliefs about an object and the attitude toward the object. In Readings in Attitude Theory and Measurement; Fishbein, M., Ed.; John Wiley \& Sons: New York, NY, USA, 1967; pp. 389-400. [CrossRef]

87. Kim, S.; Lee, J.; Yoon, D. Norms in social media: The application of theory of reasoned action and personal norms in predicting interactions with Facebook page like ads. Commun. Res. Rep. 2015, 32, 322-331. [CrossRef]

88. Arpaci, I. The influence of social interactions and subjective norms on social media postings. J. Inf. Knowl. Manag. 2020, 19, 2050023. [CrossRef] 
89. Katz, E.; Blumler, J.G.; Gurevitch, M. Uses and gratifications research. Public Opin. Q. 1973, 37, 509-523. [CrossRef]

90. Alhabash, S.; Chiang, Y.H.; Huang, K. MAM \& U\&G in Taiwan: Differences in the uses and gratifications of Facebook as a function of motivational reactivity. Comput. Hum. Behav. 2014, 35, 423-430. [CrossRef]

91. Lee, C.S.; Ma, L. News sharing in social media: The effect of gratifications and prior experience. Comput. Hum. Behav. 2012, 28, 331-339. [CrossRef]

92. Wang, Z.; Tchernev, J.M.; Solloway, T. A dynamic longitudinal examination of social media use, needs, and gratifications among college students. Comput. Hum. Behav. 2012, 28, 1829-1839. [CrossRef]

93. Rubin, A.M. Uses-and-gratifications perspective on media effects. In Media Effects; Routledge: London, UK, 2009; pp. 181-200.

94. Hsiao, C.H.; Chang, J.J.; Tang, K.Y. Exploring the influential factors in continuance usage of mobile social Apps: Satisfaction, habit, and customer value perspectives. Telemat. Inform. 2016, 33, 342-355. [CrossRef]

95. Sevi, B.; Aral, T.; Eskenazi, T. Exploring the hook-up app: Low sexual disgust and high sociosexuality predict motivation to use Tinder for casual sex. Personal. Individ. Differ. 2018, 133, 17-20. [CrossRef]

96. Brandtzaeg, P.B.; Heim, J. Why people use social networking sites. In Proceedings of the International Conference on online Communities and Social Computing, San Diego, CA, USA, 19-24 July 2009; pp. 143-152.

97. VanMeter, R.; Syrdal, H.A.; Powell-Mantel, S.; Grisaffe, D.B.; Nesson, E.T. Don't just "Like" me, promote me: How attachment and attitude influence brand related behaviors on social media. J. Interact. Mark. 2018, 43, 83-97. [CrossRef]

98. Kowalczyk, C.M.; Pounders, K.R. Transforming celebrities through social media: The role of authenticity and emotional attachment. J. Prod. Brand Manag. 2016, 25, 345-356. [CrossRef]

99. $\mathrm{Xu}, \mathrm{J} . ; \mathrm{Han}, \mathrm{R}$. The influence of place attachment on pro-environmental behaviors: The moderating effect of social media. Int. J. Environ. Res. Public Health 2019, 16, 5100. [CrossRef] [PubMed]

100. $\mathrm{Wu}, \mathrm{G} . ; \mathrm{Hu}, \mathrm{X} . ; \mathrm{Wu}, \mathrm{Y}$. Effects of perceived interactivity, perceived web assurance and disposition to trust on initial online trust. $J$ -Comput.-Mediat. Commun. 2010, 16, 1-26. [CrossRef]

101. $\mathrm{Wu}, \mathrm{G}$. The mediating role of perceived interactivity in the effect of actual interactivity on attitude toward the website. J. Interact. Advert. 2005, 5, 29-39. [CrossRef]

102. Gao, Q.; Rau, P.L.P.; Salvendy, G. Perception of interactivity: Affects of four key variables in mobile advertising. Int. J. Hum. Comput. Interact. 2009, 25, 479-505. [CrossRef]

103. Merrilees, B.; Fry, M.L. E-trust: The influence of perceived interactivity on e-retailing users. Mark. Intell. Plan. 2003, 21, 123-128. [CrossRef]

104. Elkaseh, A.; Wong, K.W.; Fung, C. Perceived ease of use and perceived usefulness of social media for e-learning in Libyan higher education: A structural equation modeling analysis. Int. J. Inf. Educ. Technol. 2016, 6, 192-199. [CrossRef]

105. Downes, E.J.; Mcmillan, S.J. Defining interactivity: A qualitative identification of key dimensions. New Media Soc. 2000, 2, 157-179. [CrossRef]

106. Mcmillan, S.; Hwang, J.S. Measures of perceived interactivity: An exploration of the role of direction of communication, user control, and time in shaping perceptions of interactivity. J. Advert. 2013, 31, 29-42. [CrossRef]

107. Xu, X.; Yao, Z.; Sun, Q. Social media environments effect on perceived interactivity: An empirical investigation from WeChat moments. Online Inf. Rev. 2019, 43, 239-255. [CrossRef]

108. Lee, J.; Lee, C. Extension of TAM by perceived interactivity to understand usage behaviors on ACG social media sites. Sustainability 2019, 11, 5723. [CrossRef]

109. Abdullah, D.; Jayaraman, K.; Shariff, D.N.; Bahari, K.; Nor, N.M. The effects of perceived interactivity, perceived ease of use and perceived usefulness on online hotel booking intention: A conceptual framework. Int. Acad. Res. J. Soc. Sci. 2017, 3, 16-23.

110. Hair, J.F.; Hult, G.T.M.; Ringle, C.; Sarstedt, M. A Primer on Partial Least Squares Structural Equation Modeling (PLS-SEM), 2nd ed.; SAGE Publications, Inc.: Thousand Oaks, CA, USA, 2017.

111. Gefen, D.; Rigdon, E.E.; Straub, D. An update and extension to sem guidelines for administrative and social science research. MIS Q. 2011, 35, iii-xiv. [CrossRef]

112. Ringle, C.M.; Sarstedt, M.; Straub, D.W. Editor's comments: A critical look at the use of PLS-SEM in "MIS Quarterly". MIS Q. 2012, 36, iii-xiv. [CrossRef]

113. Wixom, B.; Watson, H. An empirical investigation of the factors affecting data warehousing success. MIS Q. 2001, $25,17-41$. [CrossRef]

114. Nunnally, J.C. Psychometric Theory 3E; Tata McGraw-Hill Education: New York, NY, USA, 1994.

115. Bagozzi, R.P.; Yi, Y. On the evaluation of structural equation models. J. Acad. Mark. Sci. 1988, 16, 74-94. [CrossRef]

116. Fornell, C.; Larcker, D.F. Evaluating structural equation models with unobservable variables and measurement error. J. Mark. Res. 1981, 18, 39-50. [CrossRef]

117. Barclay, D.; Higgins, C.; Thompson, R. The partial least squares (PLS) approach to casual modeling: Personal computer adoption ans use as an Illustration. Technol. Stud. 1995, 2, 285-309.

118. Chin, W.W.; Marcolin, B.L.; Newsted, P.R. A partial least squares latent variable modeling approach for measuring interaction effects: Results from a monte carlo simulation study and an electronic-mail emotion/adoption study. Inf. Syst. Res. 1996, 14, 189-217. [CrossRef]

119. Goodyear, V.A.; Armour, K.M. Young People, Social Media and Health; Routledge: London, UK, 2019. 
120. Chillakuri, B.; Mahanandia, R. Generation Z entering the workforce: The need for sustainable strategies in maximizing their talent. Hum. Resour. Manag. Int. Dig. 2018, 26, 34-38. [CrossRef]

121. Bright, L.F.; Kleiser, S.B.; Grau, S.L. Too much Facebook? An exploratory examination of social media fatigue. Comput. Hum. Behav. 2015, 44, 148-155. [CrossRef]

122. Mombeuil, C.; Uhde, H. Relative convenience, relative advantage, perceived security, perceived privacy, and continuous use intention of China's WeChat Pay: A mixed-method two-phase design study. J. Retail. Consum. Serv. 2021, 59, 102384. [CrossRef]

123. Arnone, M.P.; Small, R.V.; Chauncey, S.A.; McKenna, H.P. Curiosity, interest and engagement in technology-pervasive learning environments: A new research agenda. Educ. Technol. Res. Dev. 2011, 59, 181-198. [CrossRef]

124. Voorveld, H.A.M.; van Noort, G.; Muntinga, D.G.; Bronner, F. Engagement with social media and social media advertising: The differentiating role of platform type. J. Advert. 2018, 47, 38-54. [CrossRef]

125. Xinhua, C.D. China Unveils 10-Year Plan for Youth Development. 2017. Available online: https://www.chinadaily.com.cn/ china/2017-04/14/content_28921868.htm (accessed on 5 August 2021).

126. Monacis, L.; de Palo, V.; Griffiths, M.D.; Sinatra, M. Social networking addiction, attachment style, and validation of the Italian version of the Bergen Social Media Addiction Scale. J. Behav. Addict. 2018, 6, 178-186. [CrossRef] [PubMed]

127. Whittaker, E.; Kowalski, R.M. Cyberbullying via social media. J. Sch. Violence 2018, 14, 11-29. [CrossRef]

128. Patton, D.U.; Hong, J.S.; Ranney, M.; Patel, S.; Kelley, C.; Eschmann, R.; Washington, T. Social media as a vector for youth violence: A review of the literature. Comput. Hum. Behav. 2018, 35, 548-553. [CrossRef]

129. Marwick, A.; Boyd, D. The Drama! Teen Conflict, Gossip, and Bullying in Networked Publics. A Decade in Internet Time: Symposium on the Dynamics of the Internet and Society. September 2011. Available online: https://ssrn.com/abstract=1926349 (accessed on 5 August 2021). 